\title{
DNA barcoding reveals high levels of genetic diversity in the fishes of the Itapecuru Basin in Maranhão, Brazil
}

\author{
M.H.S. Nascimento, M.S. Almeida, M.N.S. Veira, D. Limeira Filho, \\ R.C. Lima, M.C. Barros and E.C. Fraga \\ Laboratório de Genética e Biologia Molecular, \\ Departamento de Química e Biologia, Universidade Estadual do Maranhão, \\ Morro do Alecrim, MA, Brasil \\ Corresponding author: E.C. Fraga \\ E-mail: elmaryfraga@yahoo.com.br \\ Genet. Mol. Res. 15 (3): gmr.15038476 \\ Received January 21, 2016 \\ Accepted March 11, 2016 \\ Published August 29, 2016 \\ DOI http://dx.doi.org/10.4238/gmr.15038476
}

Copyright (C) 2016 The Authors. This is an open-access article distributed under the terms of the Creative Commons Attribution ShareAlike (CC BY-SA) 4.0 License.

\begin{abstract}
DNA barcoding is a useful complementary tool for use in traditional taxonomic studies due to its ability to detect cryptic species, and may be particularly efficient in the identification of fish species. The fish fauna of the Itapecuru River represents an important fishery resource in the Brazilian State of Maranhão, although it is currently suffering increasing degradation as a result of anthropogenic impacts. Therefore, DNA barcoding was used in the present study to identify fish species and establish a database of the rich freshwater fish fauna of Maranhão. A total of 440 specimens were analyzed, corresponding to 64 species belonging to 59 genera, 31 families, and 10 orders. Overall, $92.19 \%$ of these species could be identified by DNA barcoding, and were characterized by low levels (average $0.80 \%$ ) of intra-specific divergence. However, five species (Anableps anableps, Gymnotus
\end{abstract}


carapo, Sciades couma, Pseudauchenipterus nodosus, and Leporinus piau) presented values of mean genetic divergence above 3\%, indicating the existence of cryptic diversity in these fishes. The DNA barcoding approach permitted the analysis of a large number of specimens and facilitated the discrimination and identification of closely related fish species in the Itapecuru Basin.

Key words: Fish; Maranhão; Fish identification; Itapecuru basin; DNA barcoding; Cytochrome oxidase I

\section{INTRODUCTION}

Since the beginning of the 21st century, DNA barcoding has received increasing attention from taxonomists worldwide, due to its potential to standardize the identification of all lifeforms. In particular, DNA barcoding has become an important complementary tool for traditional taxonomic studies, especially for the identification of cryptic species (Molbo et al., 2003; Hebert et al., 2004).

The freshwater fish fauna of South America is considered to be the most diverse on the planet, with approximately 6000 known species, and an estimated 8000 total species (Schaefer, 1998; Reis et al., 2003; Turner et al., 2004). However, in many cases, the evolutionary processes resulting in this diversity are difficult to understand due to the reduced morphological variability found in Neotropical fishes. In Brazil, approximately $25 \%$ of the region's freshwater fish species have been described, including at least 3261 known forms (Lewinsohn and Prado, 2005). This diversity has attracted the attention of the scientific community, through studies based on the molecular identification of fish species (Henriques, 2010; de Carvalho et al., 2011; Ribeiro et al., 2012; Pereira et al., 2013); however, these analyses are limited in comparison to the country's hydrological potential.

The diversity of Brazilian fishes is poorly known in scientific terms, and the fauna of the State of Maranhão may be even less well-known than that of most other states. In fact, studies on the taxonomy, ecology, and biogeography of the fishes of Maranhão are practically non-existent, which is a preoccupying situation, given the major transformations taking place in the state as a result of anthropogenic impacts, which may lead to the extinction of certain as-yet unidentified species. Two studies analyzing morphological evidence have focused on the diversity of fish in the Itapecuru River. In the first study (Piorski et al., 1998), 41 species belonging to 36 genera and 13 families were identified on the lower Itapecuru, while in the second, more comprehensive study (Barros et al., 2011), 69 species representing 65 genera, 29 families, and 10 orders, were identified in the three sectors of the basin.

The basin of the Itapecuru River is contained wholly within the Brazilian State of Maranhão, where it has considerable historical significance. In fact, this river was a focal point during the colonization of the state due to its role in agricultural production. Furthermore, until the 20th century, it was the primary route used to transport products between the southern and northern regions of the state (Feitosa, 1983; Feitosa and Almeida, 2002; Alcântara, 2004). The importance of this river for the region's economy, together with climate change and the burgeoning growth of the local population, has contributed to the declining quality of its waters, which has had profound effects on the fauna and flora of the whole basin. Therefore, we used DNA barcoding techniques to identify fish specimens in the Itapecuru Basin, providing the first molecular data on the rich freshwater fish fauna of the Brazilian State of Maranhão.

Genetics and Molecular Research 15 (3): gmr.15038476 


\section{MATERIAL AND METHODS}

\section{Sampling}

All the specimens analyzed in the present study were collected in accordance with Brazilian environmental legislation, and the collection of biological samples was authorized by the Brazilian Federal Institute for the Environment and Renewable Natural Resources (IBAMA) through license number 02012.004159/2006.

A total of 440 fish specimens were collected. Following the analysis of morphological characteristics, a small fragment of muscle tissue was extracted for genetic analyses and conserved in $95 \%$ ethanol. Voucher specimens were deposited in the zoological collections of the Zoology Museums of the University of São Paulo and Londrina State University. The sample points were selected strategically according to the characterization of the Itapecuru Basin with the upper, middle, and lower stretches (Bezerra, 1984) of the river being sampled during eight expeditions (Figure 1).

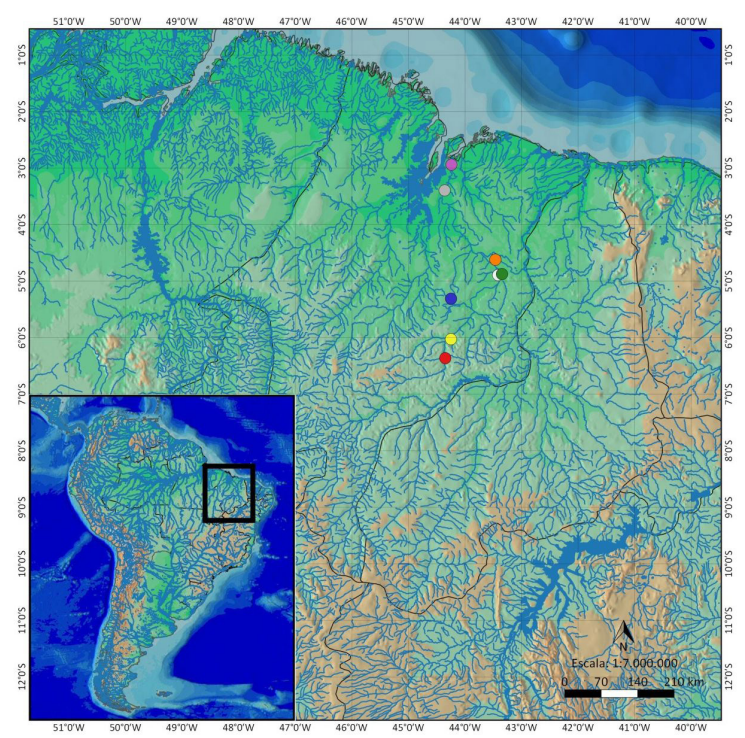

Figure 1. Map of the basin of the Itapecuru River in Maranhão (Brazil), modified from Barros et al. (2011) by Limeira Filho. Collecting points: purple: Rosário; gray: Itapecurumirim; orange: Aldeias Altas; green: Caxias; white: APA do Inhamum; blue: Governador Eugênio Barros; yellow: Colinas; red: Mirador.

\section{DNA extraction, amplification, and sequencing}

Total DNA was extracted from muscle tissue using three different approaches: a phenol-chloroform protocol (Sambrook and Russell, 2001), a commercial Promega kit, and the plate method (Ivanova et al., 2006). A 650-bp sequence from the 5'-region of the cytochrome oxidase I (COI) gene was isolated using the primers COIF1/COIR1 (Ward et al., 2005) and COIL6252Asn-/COIH7271COXI5 (Melo et al., 2011). Polymerase chain reaction (PCR) was performed in a final volume of $25 \mu \mathrm{L}$, containing $1 \mu \mathrm{L} 250 \mathrm{ng} / \mu \mathrm{L}$ DNA, $0.25 \mu \mathrm{L}(200 \mathrm{ng} / \mu \mathrm{L})$ 
of each primer (forward and reverse), $2.5 \mu \mathrm{L} \mathrm{10X}$ buffer, $4 \mu \mathrm{L} 1.25 \mathrm{M}$ DNTPs, $0.5 \mu \mathrm{L} 50 \mathrm{mM}$ $\mathrm{MgCl}_{2}, 0.2 \mu \mathrm{L} 5 \mathrm{U} / \mu \mathrm{L}$ Taq DNA polymerase, and distilled water to the final reaction volume.

The PCR protocols varied according to the combination of primers used. For the first pair (COIF1/COIR1), the protocol consisted of an initial denaturation of $2 \mathrm{~min}$ at $95^{\circ} \mathrm{C}$, followed by 35 cycles of $30 \mathrm{~s}$ at $94^{\circ} \mathrm{C}, 60 \mathrm{~s}$ at $56^{\circ} \mathrm{C}$, and $60 \mathrm{~s}$ at $72^{\circ} \mathrm{C}$, and a final extension of $7 \mathrm{~min}$ at $72^{\circ} \mathrm{C}$. For the second combination of primers, the PCR consisted of an initial denaturation of $5 \mathrm{~min}$ at $96^{\circ} \mathrm{C}$, followed by 35 cycles of $45 \mathrm{~s}$ at $96^{\circ} \mathrm{C}, 45 \mathrm{~s}$ at $54^{\circ} \mathrm{C}$, and $60 \mathrm{~s}$ at $72^{\circ} \mathrm{C}$, and a final extension of $1 \mathrm{~min}$ at $72^{\circ} \mathrm{C}$.

The PCR products were purified using an ExoSap-IT kit (USB Corporation), according to the manufacturer recommendations. DNA sequencing was performed using the purified products (Sanger et al., 1977) with the BigDye Terminator v.3.1 Cycle Sequencing Ready Reaction kit (Applied Biosystems, Foster City, CA, USA). Sequences were obtained in an ABI 3500 automatic sequencer (Applied Biosystems).

Information on the number of voucher specimens, taxonomy, the specimen collectors, collection dates, and the institutions at which the specimens are deposited can be found on the Barcode of Life Database, BOLD (http://www.boldsystems.org/) within the scope of the "DNA Barcodes of fishes from the Itapecuru River Basin" project.

\section{Data analysis}

Sequence quality was tested using Geneious (Drummond et al., 2011), considering the three categories for the formation of contigs (low, medium, and high quality). The sequences generated in the forward and reverse directions were edited and aligned in BIOEDIT (Hall, 1999). Genetic distances were calculated using the Kimura-2 parameter substitution model (Kimura, 1980). The dendrograms were based on the neighbor-joining method (Saitou and Nei, 1987), run in MEGA 6 (Tamura et al., 2013). The significance of the defined clades was estimated using bootstrap analysis (Felsenstein, 1985).

\section{RESULTS}

The 440 samples analyzed in the present study generated a library of data corresponding to 64 species belonging to 59 genera, 31 families, and 10 orders (Table 1). The orders Characiformes and Siluriformes contained the largest numbers of species, whereas Mugiliformes, Beloniformes, and Pleuronectiformes were each represented by a single species ( $\underline{\text { Figures S1 }}, \underline{\mathbf{S 2}}, \underline{\mathbf{S 3}}, \underline{\mathbf{S 4}}$ and $\underline{\mathbf{S 5}}$ ).

Using the $2-3 \%$ species cut-off criterion, a total of 59 species were identified, of which, six $(9.37 \%)$ were represented by a single specimen (singletons). However, for five ( $7.81 \%$ ) species, the mean genetic difference among specimens was higher than $3 \%$, which is greater than the species cut-off point selected for the present study.

In $92.19 \%$ of cases, the species identified by DNA barcoding corresponded to those defined based on the analysis of morphological traits. Low levels of intra-specific genetic divergence were observed (Figure 2), with $93.12 \%$ of distances ranging between 0 and 3\% (54 species, excluding singletons), while $79.95 \%$ of the intra-generic distances (44 genera, excluding singletons) were also lower than 3\% (Figure 2). On average, the intra-specific distances were approximately 30 times lower than the inter-specific distances $(25.63 \%)$, giving a mean of $0.80 \%$ (excluding singletons); however, values ranged from 0.0 to $8.09 \%$ (Table 2).

Genetics and Molecular Research 15 (3): gmr.15038476 
Table 1. Fish taxa collected in the basin of the Itapecuru River analyzed in the present study using the cytochrome oxidase I (COI) gene.

\begin{tabular}{|c|c|c|c|}
\hline \multicolumn{4}{|c|}{ Taxa } \\
\hline Order & Family & Number of genera & Number of species \\
\hline \multirow[t]{7}{*}{ Siluriformes } & Heptapteridae & 2 & 3 \\
\hline & Ariidae & 2 & 2 \\
\hline & Auchenipteridae & 4 & 5 \\
\hline & Doradidae & 2 & 2 \\
\hline & Pimelodidae & 4 & 5 \\
\hline & Trychomycteridae & 1 & 1 \\
\hline & Loricariidae & 3 & 3 \\
\hline \multirow[t]{10}{*}{ Characiformes } & Prochilodontidae & 1 & 1 \\
\hline & Cynodontidae & 1 & 1 \\
\hline & Characidae & 6 & 6 \\
\hline & Lebiasinidae & 1 & 1 \\
\hline & Serrasalmidae & 4 & 4 \\
\hline & Curimatidae & 3 & 3 \\
\hline & Acestrorhynchidae & 1 & 1 \\
\hline & Erythrinidae & 1 & 1 \\
\hline & Anostomidae & 2 & 2 \\
\hline & Hemiodontidae & 1 & 1 \\
\hline \multirow[t]{4}{*}{ Gymnotiformes } & Sternopygidae & 1 & 1 \\
\hline & Gymnotidae & 1 & 1 \\
\hline & Apteronotidae & 1 & 1 \\
\hline & Rhamphichtyidae & 1 & 1 \\
\hline \multirow[t]{3}{*}{ Perciformes } & Scianidae & 2 & 2 \\
\hline & Centropomidae & 1 & 1 \\
\hline & Cichlidae & 6 & 6 \\
\hline Mugiliformes & Mugilidae & 1 & 1 \\
\hline Clupeiformes & Engraulidae & 1 & 2 \\
\hline \multirow[t]{2}{*}{ Cyprinodontiformes } & Rivulidae & 1 & 1 \\
\hline & Anablepidae & 1 & 1 \\
\hline Synbranchiformes & Synbranchidae & 1 & 2 \\
\hline Beloniformes & Belonidae & 1 & 1 \\
\hline \multirow[t]{2}{*}{ Pleuronectiformes } & Anchiridae & 1 & 1 \\
\hline & Total & 59 & 64 \\
\hline
\end{tabular}

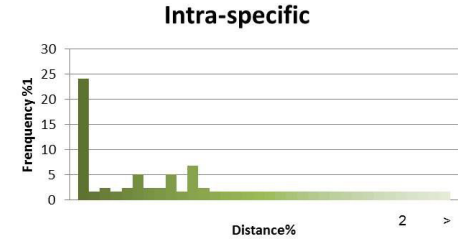

Intra-family

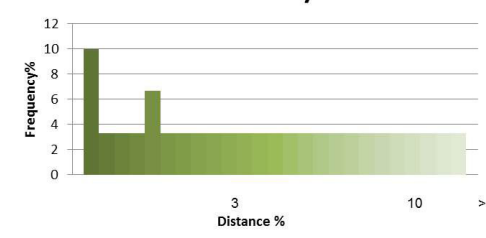

Intra-genus

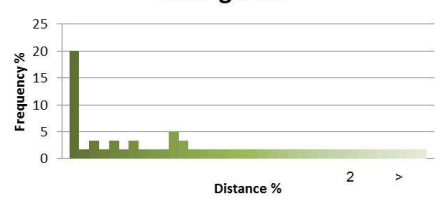

Intra-order

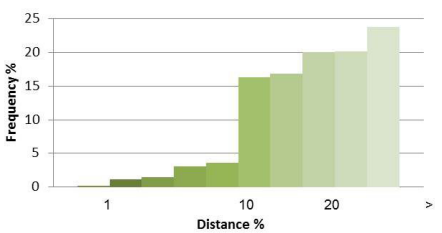

Figure 2. Distribution of genetic distances at different taxonomic levels for the fish specimens collected in the Itapecuru Basin in Maranhão, Brazil.

Genetics and Molecular Research 15 (3): gmr.15038476 
Table 2. Mean genetic distances (Kimura-2 parameter) and standard deviations for the different taxonomic levels (excluding singletons) of the fish specimens collected from the Itapecuru Basin, Maranhão (Brazil).

\begin{tabular}{l|c|c|c|c|c}
\hline \multicolumn{7}{|c}{ Mean genetic distance (\%) } \\
\hline Comparison & Number & Minimum & Mean & Maximum & Standard deviation \\
\hline Intra-species & 58 & 0 & 0.80 & 8.09 & 0.002 \\
\hline Intra-genus & 4 & 2.65 & 5.13 & 7.70 & 0.006 \\
\hline Intra-family & 12 & 5.29 & 11.69 & 21.94 & 0.010 \\
\hline Intra-order & 7 & 3.02 & 10.65 & 23.74 & 0.011 \\
\hline
\end{tabular}

Of note, the species Anableps anableps, Gymnotus carapo, Pseudauchenipterus nodosus, Sciades couma, and Leporinus piau presented intra-specific distances of over 3\%, and clearly defined subclades (Table 3 and Figure 3). A. anableps was one of the most variable species, with distances of $0-11.61 \%$ between individuals, and a mean divergence of $6.56 \%$, forming two distinct clades (Table 3 and Figure 3A).

Table 3. Genetic distances (Kimura-2 parameter) in the five species from the Itapecuru Basin, Maranhão (Brazil) with mean intra-specific distances greater than $3 \%$.

\begin{tabular}{|c|c|c|c|c|c|c|}
\hline \multirow[t]{2}{*}{ Species } & \multicolumn{3}{|c|}{ Intra-specific distance } & \multirow{2}{*}{$\begin{array}{l}\text { Number of } \\
\text { subclades }\end{array}$} & \multirow{2}{*}{$\begin{array}{c}\text { Inter-subclade } \\
(\%)\end{array}$} & \multirow{2}{*}{$\begin{array}{c}\text { Intra-subclade } \\
(\%)\end{array}$} \\
\hline & Minimum & Mean & Maximum & & & \\
\hline Anableps anableps & 0 & 6.56 & 11.61 & 2 & $5.89-11.61$ & $0-6.30$ \\
\hline Gymnotus carapo & - & 8.09 & - & 2 & 8.09 & - \\
\hline Pseudauchenipterus nodosus & - & 3.67 & - & 2 & 3.67 & - \\
\hline Sciades couma & 0 & 3.23 & 5.96 & 2 & $4.12-5.96$ & $0-4.50$ \\
\hline Leporinus piau & 0 & 3.68 & 4.00 & 2 & $3.51-4.00$ & $0-0.11$ \\
\hline
\end{tabular}

A

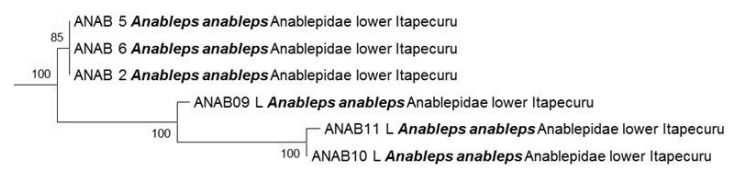

C

PSEUD $01 \mathrm{H}$ Pseudauchenipterus nodosus Auchenipteridae lower Itapecuru

$100+$ PSEUD $02 \mathrm{H}$ Pseudauchenipterus nodosus Auchenipteridae lower Itapecuru
B

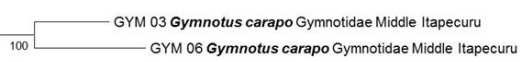

D

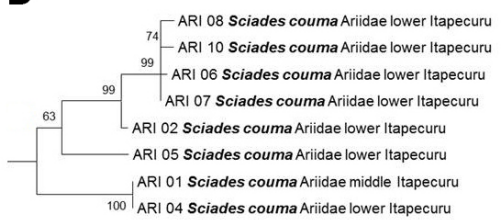

Figure 3. Neighbor-joining dendrograms based on 1000 bootstrap replicates of the cytochrome oxidase I (COI) sequences of four fish species that presented intra-specific genetic distances (Kimura-2 parameter) higher than 3\%. A. Anableps anableps; B. Gymnotus carapo; C. Pseudauchenipterus nodosus; D. Sciades couma.

For G. carapo, the mean genetic distance was $8.09 \%$ (Table 3 and Figure 3B), and when the data were analyzed using similarity indices calculated in BLAST and BOLD, this species was found to be more than $97 \%$ similar to G. chaviro, G. Pantanal, and G. carapo. 
The P. nodosus specimens diverged by $3.67 \%$ (Table 3 and Figure 3C), whereas the BOLD analysis revealed a low percentage, which impeded any conclusive inference on the species status of the sample.

The considerable intra-specific distances found in S. couma also resulted in the formation of two subclades (Table 3 and Figure 3D). When the data were analyzed by clade, one presented internal genetic distances of $0 \%$, and the other, distances ranging from 0 to $4.50 \%$, with a mean of $1.76 \%$.

In the case of $L$. piau, the mean genetic distance between specimens was $1.67 \%$, although the specimens were divided into two subclades, with distances between these subclades ranging from 0 to $4 \%$, with a mean of 3.68\% (Table 3 and Figure 4). Within-clade divergence was $0 \%$ in the first subclade and $0.00-0.48 \%$ in the second (data not shown) with a mean of $0.11 \%$.

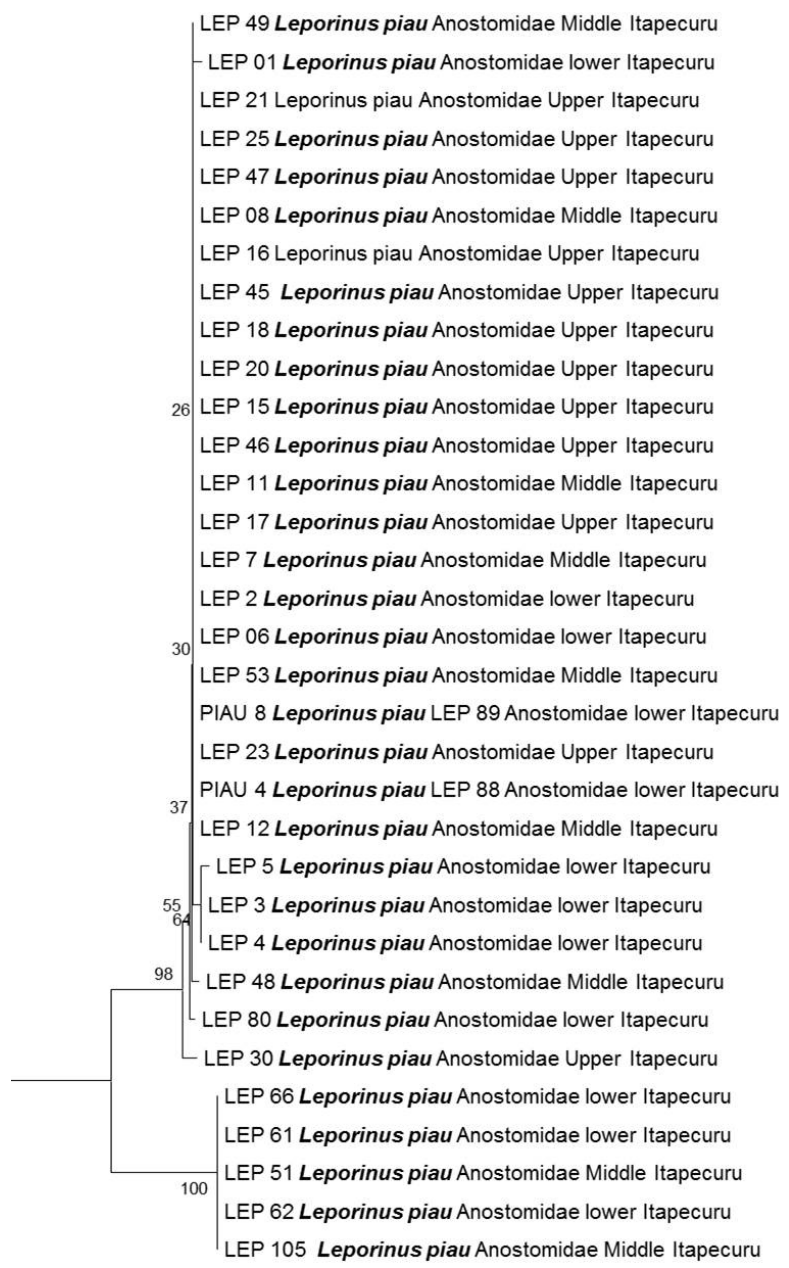

Figure 4. Neighbor-joining dendrogram based on 1000 bootstrap replicates of the cytochrome oxidase I (COI) sequences from Leporinus piau (Kimura-2 parameter), which, despite presenting a mean intra-specific of less than $2 \%$, returned high genetic distances in the pairwise analysis of the sequences. 


\section{DISCUSSION}

More than a decade after it was proposed that DNA fragments could be used to identify species (Hebert et al., 2003), different criteria have been suggested for the differentiation of species, such as a $1 \%$ level of divergence (Ratnasingham and Hebert, 2007), a value equivalent to 10 times the mean intra-specific distance (Hebert et al., 2004), and the barcoding gap (Meyer and Paulay, 2005). For Neotropical fish, however, a level of differentiation between 2 and 3\% is usually considered (de Carvalho et al., 2011; Pereira et al., 2011, 2013); this criterion was adopted in the present study to analyze 59 species identified based on morphological criteria.

DNA barcoding results for specimens from the Itapecuru Basin provided a discrimination rate of $92.19 \%$. Previous studies have demonstrated the efficiency of this technique when used to identify fish species, with intra-specific variation of between 98 and 100\% (de Carvalho et al., 2011; Pereira et al., 2011, 2013), although for freshwater fishes and marine fish species these values were 93 and 98\%, respectively (Ward et al., 2009).

In the present study, mean intra-specific genetic distances were significantly smaller than mean inter-specific distances, emphasizing the precision of the barcoding technique for the identification of 54 fish species found in the Itapecuru Basin. However, five species were characterized as having high intra-specific distances, which also reveals the potential of DNA barcoding for the identification of cryptic variation among morphologically similar specimens. This reinforces the need for a combined approach, based on the identification of morphological and molecular traits. Where intra-specific divergence exceeds the cut-off limit for the definition of a species, the molecular evidence indicates the existence of more species than are identified by morphological analysis.

Considerable genetic diversity has also been found in populations of $A$. anableps from the northern (Amazon) coast of Brazil (Watanabe et al., 2014), where the evidence indicates the presence of four distinct mitochondrial lineages, which correlate with four distinct biogeographic regions. In this scheme, the population from the coast of Maranhão is part of the Caeté-Parnaíba lineage, characterized by significant gene flow among populations.

In the case of G. carapo, in addition to the high degree of divergence, marked similarity was found with three other Gymnotus species (Gymnotus chaviro, Gymnotus pantanal, and G. carapo) in the BOLD Systems analysis. In a study of the fish fauna of the Ribeira de Iguape basin, where four species of this genus (Gymnotus pantherinus, Gymnotus sylvius, G. carapo, and Gymnotus inaequilabiatus) are found, only G. pantherinus formed a clearly defined clade, while the other species overlapped (Henriques, 2010). As these sympatric species are difficult to identify, these findings may be explained by the misidentification of specimens, or by the presence of an alternative species of Gymnotus with similar characteristics, which is found in the Inhamum River, a tributary of the Itapecuru.

The separation of $S$. couma specimens into two well-separated clades further emphasizes the power of DNA barcoding, both for the discrimination of specimens and for the identification of novel variation, including new species. This technique may thus constitute an important complementary tool for the identification of species when the results by using morphological traits alone are inconclusive. In S. couma, DNA barcoding indicates the presence of distinct biological units that may represent a species-level process of differentiation.

Considerable variation was also found between specimens identified as L. piau from the Itapecuru Basin in an analysis of the 16S gene (Fraga et al., 2014), for which 10 haplotypes were found with a divergence of $0.2-1.9 \%$. This indicates that his species is undergoing a

Genetics and Molecular Research 15 (3): gmr.15038476 
process of genetic differentiation, albeit without population structuring. A study of genetic variability between five anostomid species (Schizodon intermedius, Schizodon nasutus, Leporinus friderici, Leporinus elongates, and Leporinus obtusidens) from the Tibagi River based on iso-enzymes also recorded a high rate of polymorphism, ranging from $16.7 \%(S$. intermedius) to $36.9 \%$ (L. friderici), reflecting high levels of differentiation (Chiari and Sodré, 1999). A second study of $L$. friderici based on microsatellite markers also revealed high levels of heterozygosity (0.54) and genetic diversity (0.750) (Olivatti et al., 2011), providing additional evidence for the differentiation of fishes of the genus Leporinus.

In L. piau from the Itapecuru Basin, evidence indicates the existence of at least two distinct biological units, and the probable differentiation of L. piau (Fraga et al., 2014). In a study of Piabina argentea in the basin of the Paraná River, DNA barcoding revealed the presence of six clades, diverging by $3.0-5.6 \%$, indicating the presence of at least five distinct species (Pereira et al., 2011).

The results of the present study confirmed the effectiveness of the COI barcode for the identification and discrimination of fish species analyzed in the Itapecuru Basin, with more than $90 \%$ of the species being determined. This approach has also been used successfully for the identification of fish species in a number of other studies (Hubert et al., 2008; de Carvalho et al., 2011; Ribeiro et al., 2012; Bellafronte et al., 2013). Considering that the Itapecuru, like many other Brazilian river basins, has considerable historic and economic value for the local riverside populations, and still contains a diverse fish fauna, the findings of the present study represent an important advance in the scientific understanding of the fauna of Maranhão.

\section{Conflicts of interest}

The authors declare no conflict of interest.

\section{ACKNOWLEDGMENTS}

We are grateful to the students of the GENBIMOL for their contributions to this study, and to the Fish Biology Laboratory at UNESP-Botucatu for the internship. Financial support for this study was provided by FAPEMA, BNB, and CAPES. We would also like to thank José Olivan Biridelli for the taxonomic identification, and all the local fishermen, who helped in specimen collection.

\section{REFERENCES}

Alcântara EH (2004). Caracterização da bacia hidrográfica do Rio Itapecuru, Maranhão. Caminhos de Geografia. 7: 97-113. Barros MC, Fraga EC and Birindelli JL (2011). Fishes from the Itapecuru River basin, state of Maranhão, northeast Brazil. Braz. J. Biol. 71: 375-380. http://dx.doi.org/10.1590/S1519-69842011000300006

Bellafronte E, Mariguela TC, Pereira LHG, Oliveira C, et al. (2013). DNA barcode of Parodontidae species from the La Plata river basin-applying new data to clarify taxonomic problems. Neotrop. Ichthyol. 3: 497-506. http://dx.doi. org $/ 10.1590 /$ S1679-62252013000300003

Bezerra AS (1984). Contribuição à geomorfologia da bacia do Itapecuru, Maranhão. Master's thesis, UNESP, Rio Claro, São Paulo.

Chiari L and Sodré LMK (1999). Genetic Variability in five species of Anostomidae (Ostariophysi-Characiformes). Genet. Mol. Biol. 4: 517-523. http://dx.doi.org/10.1590/S1415-47571999000400009

de Carvalho DC, Oliveira DAA, Pompeu PS, Leal CG, et al. (2011). Deep barcode divergence in Brazilian freshwater fishes: the case of the São Francisco River basin. Mitochondrial DNA 22 (Suppl 1): 80-86.http://dx.doi.org/10.310 9/19401736.2011.588214

Genetics and Molecular Research 15 (3): gmr.15038476 
Drummond AJ, Ashton B, Buxton S, Cheung M, et al. (2011). Geneious.5.4. Version 5.4; Biomatters Ltd. Auckland, New Zealand. Available online: http://www.geneious.com (accessed on 24 October 2011).

Feitosa AC and Almeida EP (2002). A degradação ambiental do Rio Itapecuru na sede do municipio de Codó-MA. Cad. Pesqui. 13: 31-45.

Feitosa AL (1983). O Maranhão primitivo: uma tentativa de reconstrução. Editora Augusta, São Luís, Maranhão.

Felsenstein J (1985). Confidence limits on phylogenies: An approach using the bootstrap. Evolution 39: 783-791. http:// dx.doi.org/10.2307/2408678

Fraga E, Silva LMM, Schneider H, Sampaio I, et al. (2014). Variabilidade genética em populações naturais de Leporinus piau (Anostomidae, Characiformes) da bacia do Rio Itapecuru. Rev. Tróp 2: 28-40.

Hall TA (1999). BioEdit: a user-friendly biological sequence alignment editor and analysis program for Windows 95/98/ NT. Nucleic Acids Symp. Ser. 41: 95-98.

Hebert PDN, Cywinska A, Ball SL and deWaard JR (2003). Biological identifications through DNA barcodes. Proc. Biol. Sci. 270: 313-321. http://dx.doi.org/10.1098/rspb.2002.2218

Hebert PDN, Penton EH, Burns JM, Janzen DH, et al. (2004). Ten species in one: DNA barcoding reveals cryptic species in the neotropical skipper butterfly Astraptes fulgerator. Proc. Natl. Acad. Sci. USA 101: 14812-14817. http://dx.doi. org/10.1073/pnas.0406166101

Henriques JM (2010). Identificação molecular (DNA barcoding) dos peixes da bacia do rio ribeira de Iguape e dos rios costeiros do estado de São Paulo. Doctoral thesis. Universidade Estadual de São Paulo, Botucatu, São Paulo.

Hubert N, Hanner R, Holm E, Mandrak NE, et al. (2008). Identifying Canadian freshwater fishes through DNA barcodes. PLoS One 3: e2490.http://dx.doi.org/10.1371/journal.pone.0002490

Ivanova NV, deWaard JR and Hebert PDN (2006). An inexpensive, automation-friendly protocol for recovering highquality DNA. Mol. Ecol. Notes 6: 998-1002. http://dx.doi.org/10.1111/j.1471-8286.2006.01428.x

Kimura M (1980). A simple method for estimating evolutionary rates of base substitutions through comparative studies of nucleotide sequences. J. Mol. Evol. 16: 111-120. http://dx.doi.org/10.1007/BF01731581

Lewinsohn TM and Prado PI (2005). Quantas espécies há no Brasil? Megadiversidade 1: 36-42.

Melo BF, Benine RC, Mariguela TC and Oliveira C (2011). A new species of Tetragonopterus Cuvier, 1816 (Characiformes: Characidae: Tetragonopterinae) from the rio Jari, Amapá, northern Brazil. Neotrop. Ichthyol. 9: 49-56. http://dx.doi. org $/ 10.1590 / \mathrm{S} 1679-62252011000100002$

Meyer CP and Paulay G (2005). DNA barcoding: error rates based on comprehensive sampling. PLoS Biol. 3: e422. http:// dx.doi.org/10.1371/journal.pbio.0030422

Molbo D, Machado CA, Sevenster JG, Keller L, et al. (2003). Cryptic species of fig-pollinating wasps: implications for the evolution of the fig-wasp mutualism, sex allocation, and precision of adaptation. Proc. Natl. Acad. Sci. USA 100: 5867-5872. http://dx.doi.org/10.1073/pnas.0930903100

Olivatti AM, Boni TA, Silva-Júnior NJ, Resende LV, et al. (2011). Heterologous amplification and characterization of microsatellite markers in the Neotropical fish Leporinus friderici. Genet. Mol. Res. 10: 1403-1408. http://dx.doi. org/10.4238/vol10-3gmr1020

Pereira LHG, Pazian MF, Hanner R, Foresti F, et al. (2011). DNA barcoding reveals hidden diversity in the Neotropical freshwater fish Piabina argentea (Characiformes: Characidae) from the Upper Paraná Basin of Brazil. Mitochondrial DNA 22 (Suppl 1): 87-96.http://dx.doi.org/10.3109/19401736.2011.588213

Pereira LHG, Hanner R, Foresti F and Oliveira C (2013). Can DNA barcoding accurately discriminate megadiverse Neotropical freshwater fish fauna? BMC Genet. 14: 20. http://dx.doi.org/10.1186/1471-2156-14-20

Piorski NM, Castro ACL, Pereira LG and Muniz MEL (1998). Ictiofauna do trecho inferior do rio Itapecuru, Nordeste do Brasil. Bol. Lab. Hidrobiol. 11: 15-24.

Ratnasingham S and Hebert PDN (2007). bold: The Barcode of Life Data System (http://www.barcodinglife.org). Mol. Ecol. Notes 7: 355-364. http://dx.doi.org/10.1111/j.1471-8286.2007.01678.x

Reis RE, Kullander SO and Ferraris C (2003). Check List of the Freshwater Fishes of South and Central America (CLOFFSCA), EDIPUCRS, Porto Alegre, 729.

Ribeiro AO, Caires RA, Mariguela TC, Pereira LHG, et al. (2012). DNA barcodes identify marine fishes of São Paulo State, Brazil. Mol. Ecol. Resour. 12: 1012-1020. http://dx.doi.org/10.1111/1755-0998.12007

Saitou N and Nei M (1987). The neighbor-joining method: a new method for reconstructing phylogenetic trees. Mol. Biol. Evol. 4: 406-425.

Sambrook J and Russell DW (2001). Molecular Cloning: A Laboratory Manual. Cold Spring Harbor Laboratory Press, Cold Spring Harbor, New York.

Sanger F, Nicklen S and Coulson AR (1977). DNA sequencing with chain-terminating inhibitors. Proc. Natl. Acad. Sci. USA 74: 5463-5467. http://dx.doi.org/10.1073/pnas.74.12.5463

Genetics and Molecular Research 15 (3): gmr.15038476 
Schaefer SA (1998). Conflict and resolution: impact of new taxa on phylogenetic studies of neotropical cascudinhos (Siluroidei: Loricariidae). In: Phylogeny and Classification of Neotropical Fishes (Malabarba LR, Reis RE, Vari RP, Lucena ZMS and Lucena CAS, eds.). Porto Alegre: EDIPUCRS. 375-400.

Tamura K, Stecher G, Peterson D, Filipski A, et al. (2013). MEGA6: Molecular Evolutionary Genetics Analysis version 6.0. Mol. Biol. Evol. 30: 2725-2729. http://dx.doi.org/10.1093/molbev/mst197

Turner TF, McPhee MV, Campbell P and Winemiller KO (2004). Phylogeography and interespecific genetic variation of prochilodontid fishes endemic to rivers of northern South America. J. Fish Biol. 64: 186-201. http://dx.doi. org/10.1111/j.1095-8649.2004.00299.x

Ward RD, Zemlak TS, Innes BH, Last PR, et al. (2005). DNA barcoding Australia's fish species. Philos. Trans. R. Soc. Lond. B Biol. Sci. 360: 1847-1857. http://dx.doi.org/10.1098/rstb.2005.1716

Ward RD, Hanner R and Hebert PDN (2009). The campaign to DNA barcode all fishes, FISH-BOL. J. Fish Biol. 74: 329356. http://dx.doi.org/10.1111/j.1095-8649.2008.02080.x

Watanabe LA, Vallinoto M, Neto NA, Muriel-Cunha J, et al. (2014). The past and present of an estuarine-resident fish, the "four-eyed fish" Anableps anableps (Cyprinodontiformes, Anablepidae), revealed by mtDNA sequences. PLoS One 9: e101727. http://dx.doi.org/10.1371/journal.pone.0101727

\section{Supplementary material}

Figure S1. Dendrogram for the species of the order Characiformes.

Figure S2. Dendrogram for the species of the order Siluriformes.

Figure S3. Dendrogram for the species of the order Perciformes.

Figure S4. Dendrogram for the species of the order Gymnotiformes.

Figure S5. Dendrogram for the fish species of the orders Mugiliformes, Synbranchiformes, Cyprinodontiformes, Clupeiformes, Beloniformes, and Pleuronectiformes.

Genetics and Molecular Research 15 (3): gmr.15038476 